\title{
Iron Bioavailability from Little Millet and Proso Millet Based Recipes
}

\author{
M. Mounika*, K. Uma Devi and S. Sucharitha Devi \\ Department of Foods and Nutrition, Post Graduate and Research Centre, Professor Jayashankar \\ Telangana State Agricultural University, Rajendranagar, Hyderabad-500030, Telangana, India \\ *Corresponding author
}

\begin{tabular}{|c|c|}
\hline & A B S T R A C T \\
\hline & The present study entitled "Bioavailability of iron from little millet and proso millet based \\
\hline Keywords & $\begin{array}{l}\text { recipes" was conducted on four millet preparations namely dosa, idli, roti and rice, using } \\
\text { two millets namely little millet and proso millet. The iron content of millets was } 2.60 \mathrm{~g} \text {, }\end{array}$ \\
\hline $\begin{array}{l}\text { Iron bioavailability, } \\
\text { Little millet. }\end{array}$ & $7.0 \mathrm{~g}$, in little millet, proso millet. Bio available iron in millet dosas was highest with $2.23 \mathrm{in}$ \\
\hline Recipes. & $\begin{array}{l}\text { proso millet dosa and lowest with } 2.15 \mathrm{mg} \text { in little millet dosa with and } 2.03 \mathrm{mg} \text { from rice } \\
\text { dosa. In millet idlis maximum } 0.57 \mathrm{mg} \text { in proso millet idli and } 0.125 \mathrm{mg} \text { in control rice idli. }\end{array}$ \\
\hline Article Info & In millet rotis maximum was found in proso millet roti with $0.10 \mathrm{mg}$ minimum was found \\
\hline $\begin{array}{l}\text { Accepted: } \\
23 \text { September } 2017 \\
\text { Available Online: } \\
10 \text { October } 2017\end{array}$ & $\begin{array}{l}\text { in millet meals was maximum in proso millet meal with } 4.39 \mathrm{mg} \text { minimum in little millet } \\
\text { meal with } 3.71 \mathrm{mg} \text {. Compared to control rice meal, proso millet meal had higher available } \\
\text { iron. Significant difference was found in the bio available iron from any two millets and } \\
\text { between millet meals and rice meal }(\mathrm{p}<0.05)\end{array}$ \\
\hline
\end{tabular}

\section{Introduction}

Bioavailability of minerals and trace elements has gained increasing interest in the field of nutrition. Unlike macronutrients, great variation in the bioavailability of minerals and trace elements exists with different foods, food components and under different gastrointestinal conditions. Low iron status, anaemia, pregnancy and growth phases increase the iron absorption from food, certain conditions like achlorohydria and increased motility decreases the iron absorption. Bioavailability studies should be determined by measurements in vivo. Human in-vivo studies, however, are time-consuming and expensive, rather complicated to perform and sometimes yield quite variable results. The in vitro techniques involved measurement of soluble or ionizable fraction of the mineral after simulated gastrointestinal digestion (Rao and Prabhavathi, 1978). An improvement of these methods involves measurement of the ionizable fraction of the dialyzes across a semi permeable membrane of certain pore size during simulated gastrointestinal digestion is conserved as the fraction that is available for absorption (bio accessible fraction). In humans, the efficiency of absorption of non- heme iron is lower than that of heme iron. The absorption of non heme iron is influenced significantly by dietary composition and iron status and the human diet contains many forms of food iron. However, iron compounds from different sources eaten together in a meal appear to have nearly identical nonheme availability for absorption.

\section{Materials and Methods}

The selected millets namely little millet and proso millet were processed and developed into two meal items i.e. millet rice and roti and two breakfast items namely idly and dosa. As control 
rice was used for idli, dosa, boiled rice and wheat was used for making roti. Basic standard preparations procedures were followed for all millet preparations. The procedures are given below.

Raw millets and black gram dhal were soaked separately for 3-4h and gronad separately into fine batter, and mixed together and fermented overnight. Salt was added to taste. Dosa was made on hot iron pan by spreading $100 \mathrm{ml}$ of batter into a typical round dosa and roasted with little oil dropped on the other circle of dosa. 50g millet and $25 \mathrm{~g}$ blackgram batter gave 2 dosas.

Regular, standard procedure of idli was followed. Each millet idli was prepared by soaking $25 \mathrm{~g}$ blackgram dal for 4-5hrs and grinding it into a fluffy batter to which each millet semolina soaked for $1 \mathrm{hr}$ (procured from Grameenmall Foundation) was added and batter was left for 6-7hrs fermentation and then added with required salt. The batter was poured in idli moulds and steamed for 7-9 minutes, Idli rava (parboiled rice semolina) was used for control idli samples.

To each of $50 \mathrm{~g}$ millet flour a pinch of salt was added. The flours were made into soft dough by pouring hot water $(20-30 \mathrm{ml})$ and kneading well. The dough ball of a big lime size was placed on wooden chappathi board and patted with fingers to spread into big, thin roti. The roti was transferred on to a hot tawa, or pan and baked on both sides till done, wheat flour was used as control roti.

Dehulled grains of little millet and proso millet were used for preparation of millet meal. The grains were soaked 1-2hrs and cooked with double the quantity of water for 7-10 minutes in open/pressure cooking to a soft meal. Rice (Oryza sativa) was used as control, which was also cooked by the same standard method.

The moisture content edible portion of the raw millets and samples analyzed using standard procedure of AOAC, (1990) in Cintex precision hot air oven. The crude protein content of the sample was estimated according to the Micro Kjeldhal Method and the ash content of the samples was determined by using the method of (AOAC, 2005). The dietary fibre content was determined by the following the rapid enzymatic method (Asp, 1987). Minerals were estimated by standard AOAC methods. Ionisable iron was estimated by Narasinga and Prabhavathi 1978 method.

\section{Results and Discussion}

All the products were analysed for proximate nutrients and minerals and estimated for in vitro iron availability. The effect of protein and fibre on in vitro availability of iron was arrived through correlation co-efficient analysis. The results of study are presented and discussed under the following headings.

The millets selected for the study were, little millet (Panicum milliare), and proso millet (Panicum miliaceum) which were some of the most important cultivated and consumed species some five to six decades back in the states of Andhra and Telangana regions of India.

The millet grains were procured from Grameenmall Foundation, Hyderabad, and a NonGovernment Organization that encouraged the farmers to cultivate millets and formed them into cooperative groups.

Moisture content is the most influential of all factors in the storage of grains. A small change in seed moisture content has a large effect on the storage life of the seeds by promoting diseases. Moisture analysis of studied millets and control (rice and wheat) revealed that in edible form varied between $9.0 \mathrm{~g}$ to 13.2. Rice, finger millet, wheat, proso millet, pearl millet and sorghum had moisture levels close to each other at $13.2 \mathrm{~g}, 12.8 \mathrm{~g}$, $12.0 \mathrm{~g}, \quad 12.0 \mathrm{~g} \quad 11.8 \mathrm{~g}, \quad 11.6 \mathrm{gg}$, and $/ 100 \mathrm{~g}$ respectively, while, little millet and foxtail millet had slightly low moisture levels of $9.0 \mathrm{~g}$ and $9.1 \mathrm{~g}$ respectively.

Moisture in inappropriate amounts and places is very damaging to the useful life of grain. Once it is reduced to the desired level the grain can then be packaged for storage.

The protein content of the millets ranged between $7.0 \mathrm{~g}$ to $12.9 \mathrm{~g} / 100 \mathrm{~g}$ (Table 1 ). Among different millets, proso millet had the highest content of protein i.e., $12.9 \mathrm{~g} \%$ and finger millet had the 
lowest protein content of $7.0 \mathrm{~g} \%$. Foxtail millet, pearl millet, sorghum and little millet had $11.9 \mathrm{~g}$, $11.2 \mathrm{~g}, 9.6 \mathrm{~g}$ and $9.4 \mathrm{~g} \%$ protein respectively. Protein content of foxtail millet and pearl millet were almost close to each other, similarly sorghum and little millet had same amount of protein. The control cereal samples of rice and wheat have 6.1 and $11.2 \mathrm{~g}$ of protein where rice was comparable to finger millet and wheat protein was par with pearl millet and foxtail millet.

The higher protein content of millets on par with most cereals, with equal energy value in comparison with cereals makes millets a good substitute for the refined rice or gluten rich wheat, both of which are not recommended for some population with metabolic disorders and those who suffer from gluten enteropathy respectively. In the pace of increasing population and stagnant wheat and rice productions, with impending metabolic diseases like diabetes, obesity, cardio vascular diseases etc among the population, millets can serve as a promising alternative food grain in solving the problems of both food insecurity and metabolic disorders.

Kalinova and Moudry (2006) reported the protein content of proso millet (11.6\% of dry matter) was found to be comparable with that of wheat and the grain of proso millet to be significantly richer in essential amino acids (leucine, isoleucine, and methionine) than wheat protein. The protein concentrate of Korean foxtail millet and proso millet significantly elevated plasma adiponectin and HDL cholesterol levels and caused major decreases in insulin levels relative to a casein diet in type 2 diabetic mice. Furthermore, proso mill et al., so improved glycemic responses and plasma levels of glucose.

Among all millets, little millet had highest content of fat with $5.0 \mathrm{~g} \%$ and the second highest being pearl and proso millets with $4.8 \mathrm{~g} \%$ and $4.7 \mathrm{~g} \%$ respectively (Table 1). The other millets foxtail, finger millet and sorghum had $4.1 \mathrm{~g}, 1.9 \mathrm{~g}$ and $1.9 \mathrm{~g}$ of fat respectively. The fat content of almost all millets were higher than that of common cereals like rice $0.6 \mathrm{~g}$ and wheat $1.2 \mathrm{~g}$.

Though, on a whole weight basis pearl millet had highest fat content, dehulling of little millet has increased the percent fat content in the millet. It is apparent that natural millet oil could be extracted and it is known that natural millet oil is a good source of linoleic acid and tocopherols.

Fat content of millets tested in the present work were close to the values reported by previous studies. Proso and little millet were reported to contain fat of about 3.5 and 4.1 per cent respectively with varietal differences (Veena et al., 2005) for various millets. Higher fat content in pearl millet compared to that of foxtail millet was reported by Anbu Malar et al., 2015.

Among all millets, finger millet had highest content of dietary fibre $11.24 \mathrm{~g} / 100 \mathrm{~g}$ and the decreasing order of dietary fibre in millets was $11.24 \mathrm{~g}$ in foxtail millet, $11.0 \mathrm{~g}$ in pearl millet, $9.7 \mathrm{~g}$ in sorghum, $9.1 \mathrm{~g}$ in proso millet and $7.0 \mathrm{~g}$ in little millet. Foxtail millet and finger millet had dietary fibre values close to each other and a similar trend was seen between dietary fibre content of proso millet and sorghum which was close to each other. Dietary fibre of rice and wheat 3.2 and $10.1 \mathrm{~g}$, rice has lower dietary fibre compared to millets.

Though foxtail millet was dehulled to make it edible, the fibre content was high and was on par with finger millet. Proso millet al.,so showed a good amount of dietary fibre of 9.1g inspite of dehulling. Little millet, owing to its small size and low surface further due to dehulling was found to have proportionately less difference compared to the rest of the millets.

Consumption of dietary fibre lowers blood glucose levels and helps to maintain normal levels and promote dietary management of type II diabetics. Dietary fibre from millets binds cholesterol and does not allow it to be absorbed, thus protect from heart diseases. Millet fibre due to its incomplete or slow fermentation by micro flora in the colon, promotes normal laxation which prevents constipation, diverticulosis and diverticulitis.

Millets generally contain 4.5 to 6.3 per cent of crude fibre (Gopalan et al., 2009). Barnyard millet was reported to contain crude fibre in the range of 5.35 to 7.90 per cent in nine different varieties (Veena et al., 2005). 
The ash content of millets ranged between $1.13 \mathrm{~g}$ in finger millet to $5.2 \mathrm{~g} \%$ in little millet. The ash content of pearl millet, foxtail millet, sorghum and proso millet was $2.2 \mathrm{~g}, 3.0 \mathrm{~g}, 1.8 \mathrm{~g}$ and $1.8 \mathrm{~g}$ per $100 \mathrm{~g}$ respectively. The higher ash content of millets indirectly indicates presence of higher mineral content in millets.

Highest iron content was seen in pearl millet with $9.0 \mathrm{mg} / 100 \mathrm{~g}$ and lowest in proso millet with $2.6 \mathrm{mg} / 100 \mathrm{~g}$. The decreasing order of iron content in millets was $9.0 \mathrm{mg}$ in pearl millet $7.0 \mathrm{mg}$ in little millet, $4.0 \mathrm{mg}$ in sorghum, $3.65 \mathrm{mg}$ in finger millet, $2.6 \mathrm{mg}$ in foxtail millet and $2.6 \mathrm{mg}$ per $100 \mathrm{~g}$ in proso millet respectively. Iron content of wheat and rice was 4.5 and $0.5 \mathrm{~g}$.

Zinc content in millets was highest in proso millet with $4.3 \mathrm{mg}$ and lowest with $2.0 \mathrm{mg}$ in finger millet. The decreasing order of percent zinc in other millets was $3.5 \mathrm{mg}$ in little millet, $2.9 \mathrm{mg}$ in pearl millet, $2.8 \mathrm{mg}$ in foxtail millet, and $2.10 \mathrm{mg}$ in sorghum per $100 \mathrm{~g}$ of grain. In rice the zinc content was $1.2 \mathrm{mg} / 100 \mathrm{~g}$ which was lower than other millets where as in wheat was observed to be $2.2 \mathrm{mg} / 100 \mathrm{~g}$.

Calcium content of finger millet was the highest compared to that of milk calcium. The percent calcium content was $342 \mathrm{mg}$ in finger millet, which was the highest. The other millets were in the order of $43.6 \mathrm{mg}$ in foxtail millet, 24.1 in pearl millet, $23.3 \mathrm{mg}$ in sorghum, $17.8 \mathrm{mg}$ in little millet and $7.6 \mathrm{mg}$ in proso millet. Calcium content of rice was $9.6 \mathrm{mg}$ which was close only to proso millet, wheat had fairy better calcium content compared to at only rice but also pearl millet, foxtail millet and sorghum. Highest zinc content was present in proso millet with $4.0 \mathrm{mg}$ and low in finger millet at $2.0 \mathrm{mg}$ and highest calcium content was found in finger millet with $342 \mathrm{mg}$ and lowest in proso millet with $7.6 \mathrm{mg} / 100 \mathrm{~g}$.

The mineral composition of millet grains was highly variable. The genetic factors and environmental conditions prevailing in the growing region affect the mineral content of these foods grains. Iron is an essential micronutrient extremely vital to human health. Identifying sources and improving iron content in millet grains would be a pertinent approach to combat wide- spreading malnutrition. Hama et al., (2011) reported that iron was more localized in the peripheral region than in the endosperm as evidenced by the fact that decortication for shorter duration removed $46 \%$ to $62 \%$ of this mineral.

\section{Processing of millets into breakfast and meal items}

The idea of processing of millets into food preparations like millet rice, roties, idli and dosa involving boiling, pan roasting, soaking and grinding to batters and then steaming or shallow frying methods was to see if these processes have any influence on nutritional compositionand nutrient availability.

The selected 6 millets, sorghum, foxtail, finger, proso, pearl and little millets were cooked into recipes as boiled millet rice, rotis, dosa and steamed idlis and then representative samples made of each recipe from each millet were analysed for protein, dietary fibre and iron content. Rice was taken as control for boiled rice, idli and dosa, while wheat was used as control for roties. The nutrient composition of the millet recipes and the standard control rice and wheat recipes on dry weight basis is given in table 1 and discussed below.

Protein content of millet recipes is given in table 1 and figure 1. Among the dosa preparations foxtail millet dosa had highest protein content of $26.5 \mathrm{~g}$ and proso millet dosa had the lowest protein of $12.4 \%$. The protein content in different millet dosas in the decreasing order was $26.5 \mathrm{~g}$ in foxtail millet dosa, $19.3 \mathrm{~g}$ in pearl millet, $17.7 \mathrm{~g}$ in sorghum dosa, $15.3 \mathrm{~g}$ in finger millet dosa, $14.8 \mathrm{~g}$ in little millet dosa and $12.4 \mathrm{~g}$ in proso millet dosa per $100 \mathrm{~g}$ on dry weight basis. When compared to $15.3 \mathrm{~g}$ protein of rice dosa, foxtail, pearl and sorghum dosas had high protein content.

Dosa made of pearl millet, foxtail millet and sorghum millets was superior in its protein content composed to traditional rice based dosa. Little millet and finger millet dosas were almost on par in their protein content compared to rice dosa. Hence, any of the six millets dosas can be readily suggested for meeting the protein requirement in any growth period as well as special physiological conditions. 


\section{Protein in millet idlis}

The protein content of foxtail millet idli was $29.8 \mathrm{~g}$ and it was highest compared to all other millet idlis, while lowest protein was seen in little millet idli with $14.1 \mathrm{~g}$. The decreasing order of protein content in millet idlis on a percent basis was $29.8 \mathrm{~g}$ in foxtail millet, $26.9 \mathrm{~g}$ in pearl millet idli, followed by finger millet idly with $22.6 \mathrm{~g}$, sorghum idli with $19.6 \mathrm{~g}$, proso idly with $16.4 \mathrm{~g}$ and least in little millet idli with $14.1 \mathrm{~g}$ protein. The traditional idli recipe made from blackgramdal and idli rawa par boiled rice milled into semolina had 21.5gprotein.

Idli made of finger millet, pearl millet and foxtail millet had higher protein than traditional rice based idly.

While sorghum, proso and little millet idlis had lower protein compared to rice, while the rice idlis, millet based idlis had lower protein compared to rice. Unlike the rice idlis, millet based idlis will have a long satiating feeling and serves as a good substitute for easily digested refined cereal based breakfasts.

\section{Protein in millet meals}

Protein content in millet meals (boiled millet) indicated that proso millet meal had the highest protein of $16 \mathrm{~g}$ compared to all other meals. The increasing order of protein content in different millet meals was $7.7 \mathrm{~g}$ in finger millet meal, followed by $10.7 \mathrm{~g}$ in pearl millet, $11.7 \mathrm{~g}$ in little millet meal and 11.7 in sorghum meal $16.0 \mathrm{~g}$ in proso meal, $14.7 \mathrm{~g}$ in foxtail meal. Normal traditional rice meal had the least protein content of $5.4 \mathrm{~g} / 100 \mathrm{~g}$ compared to any millet meal. The boiled millets just like Oryza sativa could be served as millet rice (meal) and all millet rice samples were found to have higher protein content compared to Oryza rice. The protein content of sorghum, pearl millet and little millet rice was almost double that of normal rice and protein of foxtail millet and proso millet rice was nearly thrice that of rice protein.

Fig.1 Protein content in millet/control recipes

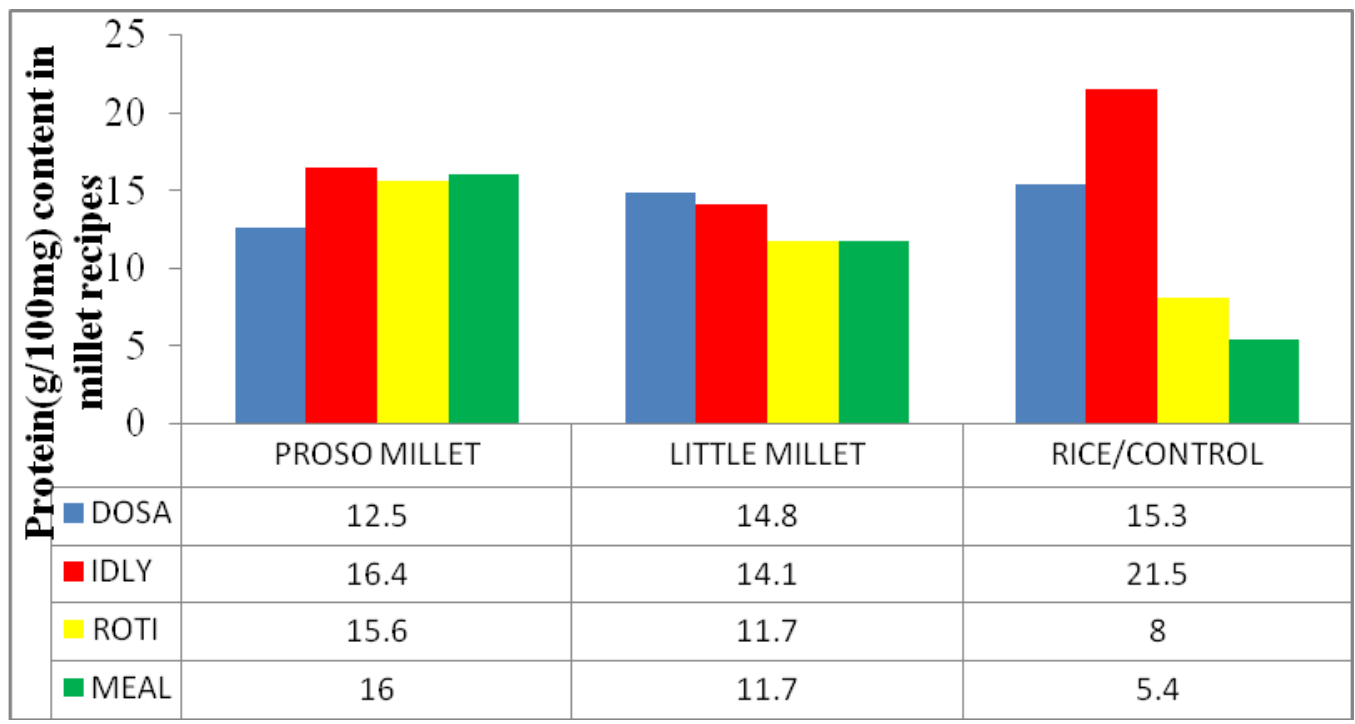


Fig.2 Dietary fibre content of millet and rice recipes

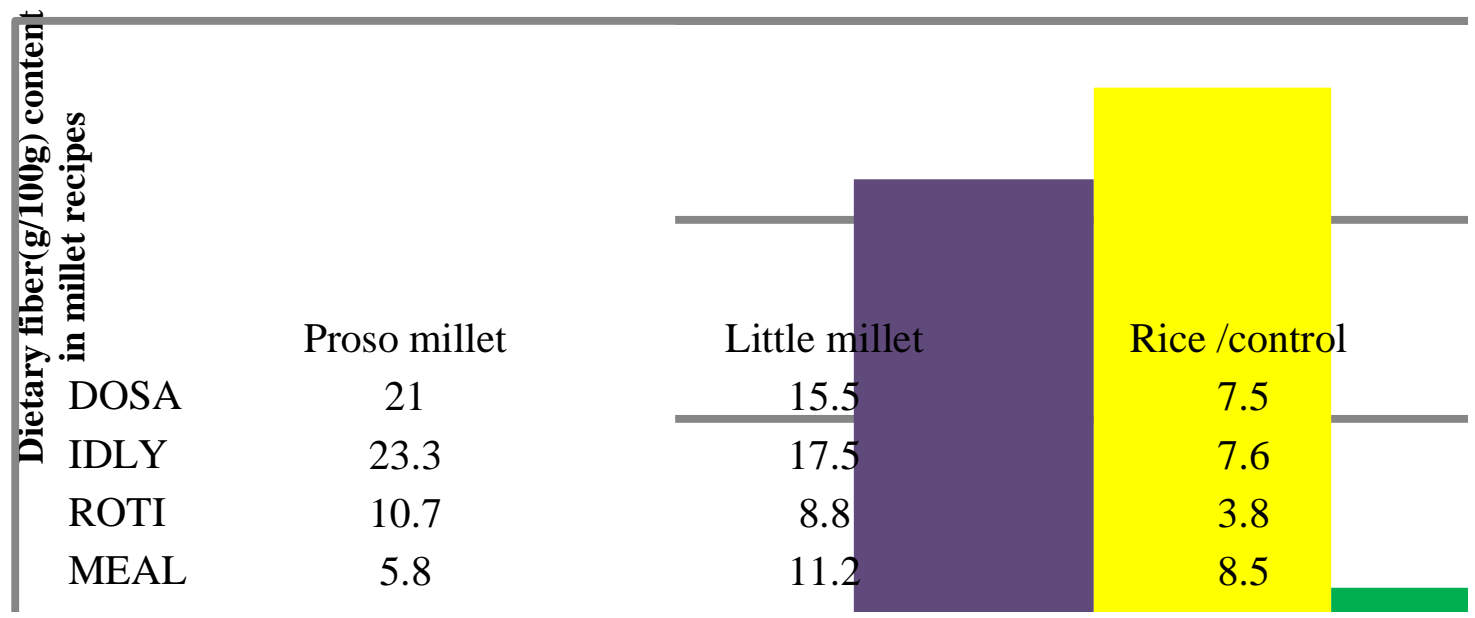

Table.1 Nutrient composition of millets and cereals

\begin{tabular}{|l|l|l|c|c|c|c|c|c|c|c|}
\hline Millets & $\begin{array}{l}\text { Moisture } \\
(\mathbf{g})\end{array}$ & $\begin{array}{l}\text { Protein } \\
(\mathbf{g})\end{array}$ & Fat (g) & $\begin{array}{l}\text { Energy } \\
(\text { Kcal })\end{array}$ & Ash (g) & $\begin{array}{l}\text { Dietary } \\
\text { fibre(g) }\end{array}$ & $\begin{array}{l}\text { Carboh } \\
\text { ydrate } \\
(\mathbf{g})\end{array}$ & $\begin{array}{l}\text { Iron } \\
(\mathbf{m g})\end{array}$ & $\begin{array}{l}\text { Zinc } \\
(\mathbf{m g})\end{array}$ & $\begin{array}{l}\text { Calcium } \\
(\mathbf{m g})\end{array}$ \\
\hline $\begin{array}{l}\text { Proso } \\
\text { millet }\end{array}$ & 12.0 & 12.1 & 4.7 & 364 & 2.8 & 9.1 & 60.8 & 2.60 & 4.30 & 7.6 \\
\hline $\begin{array}{l}\text { Little } \\
\text { millet }\end{array}$ & 9.0 & 9.4 & 5.0 & 329 & 5.20 & 7.0 & 60.9 & 7.0 & 3.50 & 17.8 \\
\hline Rice & 13.2 & 6.1 & 0.6 & 347 & 0.8 & 3.2 & 77.0 & 0.5 & 1.2 & 9.6 \\
\hline Wheat & 12.0 & 11.2 & 1.2 & 339 & 2.5 & 10.1 & 64.9 & 4.5 & 2.2 & 46 \\
\hline
\end{tabular}

Table. 2 Total iron content, available iron and percent available iron from millet/rice recipes

\begin{tabular}{|c|c|c|c|c|c|c|c|c|c|c|c|c|c|}
\hline \multirow{2}{*}{$\begin{array}{l}\text { S. } \\
\mathbf{N} \\
\text { o }\end{array}$} & \multirow[b]{2}{*}{ Millet / Grain } & \multicolumn{3}{|c|}{ Dosa } & \multicolumn{3}{|c|}{ Idly } & \multicolumn{3}{|c|}{ Roti } & \multicolumn{3}{|c|}{ Meal } \\
\hline & & $\begin{array}{l}\text { Total iron } \\
(\mathrm{mg})\end{array}$ & $\begin{array}{l}\text { Available } \\
\text { iron }(\mathrm{mg})\end{array}$ & $\begin{array}{l}\text { Available } \\
\text { iron }(\%)\end{array}$ & $\begin{array}{l}\text { Total iron } \\
\quad(\mathrm{mg})\end{array}$ & $\begin{array}{l}\text { Available } \\
\text { iron (mg) }\end{array}$ & $\begin{array}{l}\text { Available } \\
\text { iron }(\%)\end{array}$ & $\begin{array}{l}\text { Total iron } \\
\quad(\mathrm{mg}\end{array}$ & $\begin{array}{l}\text { Available } \\
\text { iron (mg) }\end{array}$ & $\begin{array}{l}\text { Available } \\
\text { iron }(\%)\end{array}$ & $\begin{array}{l}\text { Total iron } \\
(\mathrm{mg})\end{array}$ & $\begin{array}{l}\text { Available } \\
\text { iron (mg) }\end{array}$ & $\begin{array}{c}\text { Available } \\
\text { iron }(\%)\end{array}$ \\
\hline 1 & Control & $7.93^{\mathrm{a}}$ & $2.03^{c}$ & $25.6^{c}$ & $1.88^{\mathrm{c}}$ & $0.125^{\mathrm{b}}$ & $6.59^{\mathrm{a}}$ & $4.8^{\mathrm{b}}$ & $0.25^{\mathrm{a}}$ & $5.2^{\mathrm{a}}$ & $3.87^{\mathrm{b}}$ & $0.32^{\mathrm{c}}$ & $8.2^{\mathrm{b}}$ \\
\hline 2 & Proso millet & $3.89^{\mathrm{c}}$ & $2.23^{\mathrm{a}}$ & $57.7^{\mathrm{a}}$ & $4.99^{\mathrm{b}}$ & $0.57^{\mathrm{a}}$ & $11.4^{\mathrm{a}}$ & $6.91^{\mathrm{a}}$ & $0.105^{\mathrm{b}}$ & $1.51^{\mathrm{c}}$ & $4.39^{\mathrm{a}}$ & $1.20^{\mathrm{a}}$ & $27.3^{\mathrm{a}}$ \\
\hline 3 & Little millet & $4.7^{\mathrm{b}}$ & $2.15^{\mathrm{b}}$ & $45.7^{\mathrm{b}}$ & $5.39^{\mathrm{a}}$ & $0.02^{\mathrm{c}}$ & $0.46^{\mathrm{c}}$ & $4.7^{\mathrm{c}}$ & $0.08^{\mathrm{c}}$ & $1.8^{\mathrm{b}}$ & $3.71^{\mathrm{b}}$ & $0.19^{\mathrm{b}}$ & $5.3^{\mathrm{c}}$ \\
\hline & F ratio & 1529.88 & 4608.21 & 8769.62 & 1529.88 & 4608.21 & 8769.62 & 1529.88 & 4608.21 & 8769.62 & 1529.88 & 4608.21 & 8769.62 \\
\hline
\end{tabular}

\section{Protein in millet rotis}

Protein content in proso millet roti was highest with $15.6 \mathrm{~g}$ compared to all other roties. The increasing order of protein content in millet roties was $8.13 \mathrm{~g}$ in finger millet roti, $11.4 \mathrm{~g}$ in sorghum roti and $11.7 \mathrm{~g}$ in little millet roti, $14.0 \mathrm{~g}$ in pearl millet roti, $14.7 \mathrm{~g}$ foxtail millet roti and $15.6 \mathrm{~g}$ in proso millet roti, wheat chapathi or roti had $8 \mathrm{~g}$ of protein per $100 \mathrm{~g}$, and when compared to millet roties, wheat roti had the least protein content.

When the protein content of rotis was, compared with the protein of control wheat roti, all the millet rotis had higher protein content except finger millet roti which had equal quantity of protein as control. From the data it is very clear that millet recipes are far better than traditional refined rice and wheat based preparations with regard to protein content.

Among the six millets foxtail millet had the highest amount of protein in all four recipes i.e., rice, roti, idli and dosa made of not only millets but also of rice and wheat. Among the four preparations dosa, idly, roti and meal prepared 
from millets had highest mean protein. Millet and black gram dhal combination recipes idly and dosa had high amount of protein, in meal proso had the highest amount of protein due to raw grains used for proso and little millet preparations may chance to increased protein content.

The quality of protein is mainly a function of its essential amino acids. Finger millet contains $44.7 \%$ essential amino acids (Mbithi et al., 2000) found that of the total amino acids, which is higher than the $33.9 \%$ essential amino acids in FAO reference protein (FAO, 1991).

\section{Dietary fibre in millet recipes}

The dietary fibre content in millet dosas followed the increasing order from sorghum dosa with $6.8 \mathrm{~g}$ to finger millet dosa with $14.1 \mathrm{~g}$, pearl millet dosa with $14.2 \mathrm{~g}$, little millet dosa with $15.5 \mathrm{~g}$, foxtail millet dosa with $20.2 \mathrm{~g}$ and proso millet dosa with $21.0 \mathrm{~g}$ per $100 \mathrm{~g}$. Traditional rice based dosa had $7.5 \mathrm{~g}$ dietary fibre, which was lower than all millet dosas except sorghum dosa. Foxtail millet dosa and proso millet dosa had closer dietary fibre values and finger millet dosa and pearl millet dosa had similar values of dietary fibre content.

Rice idly had the least dietary fibre of $7.6 \mathrm{~g}$ compared to all millet idlis. Dietary fibre was highest in proso millet idli with $23.3 \mathrm{~g}$ followed by foxtail millet idli with $22.8 \mathrm{~g}$, finger millet idli with $20.8 \mathrm{~g}$, pearl millet with $19.7 \mathrm{~g}$, little millet idli with $17.5 \mathrm{~g}$ and least in sorghum idli with $11.8 \mathrm{~g}$ per $100 \mathrm{~g}$ (Fig. 2).

Dietary fibre of control wheat roti was $3.8 \mathrm{~g}$, which was the least of all roties. The dietary fibre content of millet roties was followed by $13.2 \mathrm{~g}$ in finger millet roti and in the increasing order of roties, $13.7 \mathrm{~g}$ in pearl millet roti, $14.0 \mathrm{~g}$ in foxtail millet roti, 5.7gin sorghum roti, $10.7 \mathrm{~g}$ in proso roti and $8.7 \mathrm{~g} / 100 \mathrm{~g}$ in little millet roti.

On an overall basis, dietary fibre content of all millet in all 4 preparations was high compared to control rice and wheat preparations. Next to the control samples, sorghum idli, rice and roti had lower dietary fibre content because dehulled sorghum grain, semolina and flour were used for the preparations.
Compared to other millet preparations foxtail millet preparations had higher dietary fibre content, followed by proso millet and then by finger millet and pearl millet preparations. Though foxtail millet and proso millet were dehulled to make them, edible they still had higher dietary fibre compared to others. Finger and pearl millet also had higher dietary fibre because they were not dehulled.

Dietary fibre was high in millet breakfast items idli and dosa, along with control rice based idli, dosa and raw millets inspite of the processing steps like soaking, grinding, fermentation and steaming. Whereas, boiling method and roasting method had slight rise compared to raw samples.

The dietary fibre content was slightly increased in millet recipes. Among the millet recipes highest dietary fibre content was found in foxtail millet idly, followed by proso millet dosa. Remaining millet products have low content of dietary fibre. Low dietary fibre content in rice products, sorghum meal and all other millet products had lower than foxtail and proso millet recipes.

\section{Iron availability from proso millet preparations}

The total iron content and in vitro available iron of proso millet preparations are dosa, idly, roti and meal are given in table 2 .

The proso millet dosa had $3.89 \mathrm{mg}$, total iron which was lowest, followed by $4.39 \mathrm{mg}$ in proso millet meal, $4.99 \mathrm{mg}$ in proso millet idli and $6.91 \mathrm{mg}$ in proso millet roti. Roti had highest content of iron compared to all other preparations of proso millet.

Though the total iron was good in all four preparations, available iron content reduced drastically to $2.239 \mathrm{mg}$ in dosa, $1.201 \mathrm{mg}$ in meal, $0.571 \mathrm{mg}$ in idli and $0.105 \mathrm{mg}$ in roti with significant difference between recipes $(\mathrm{p}<0.05)$.

The bioavailability of iron was seems to very low in dry heat method compared to other moist heat methods used in other preparations.

Percent available iron was highest in proso millet dosa at $57.7 \%$ against $11.4 \%$ from idli, $1.51 \%$ in roti and $27.3 \%$ from meal with significant difference $(\mathrm{p}<0.05)$ between preparations. 
Proso-millet based convenience mix for infants and children was developed by Srivastava et al., (2001) by malting and popping techniques. The convenience mix $(100 \mathrm{~g})$ provided $14.32 \mathrm{~g}$ protein, $82.48 \mathrm{mg}$ calcium, $4.20 \mathrm{mg}$ iron, $8.84 \mathrm{mg}$ ascorbic acid and $63.90 \mathrm{mg} \mathrm{b}$-carotene per $50 \mathrm{~g}$ of the mix.

\section{Iron availability from little millet preparations}

Little millet idli had $5.39 \mathrm{mg}$ of iron, which was the highest, followed by $4.7 \mathrm{mg}$ each in roti, and $4.7 \mathrm{mg}$ in dosa and $3.71 \mathrm{mg}$ in meal with significant difference between the recipes but not between roti and dosa. Though the total iron was good in all 4 preparations, bioavailable iron content reduced drastically to $2.153 \mathrm{mg}$ in dosa, $0.198 \mathrm{mg}$ in meal, $0.085 \mathrm{mg}$ in roti, and $0.025 \mathrm{mg}$ in idli with significant difference between the four preparations $(\mathrm{p}<0.05)$.

Percent available iron was lowest in little millet idli at $0.46 \%$, against $1.8 \%$ in roti, $5.3 \%$ in meal and $45.7 \%$ in dosa with significant difference $(\mathrm{p}<0.05)$ between each other.

\section{Iron availability from control/rice or wheat preparations}

The total iron, available iron and percent availability of iron of rice preparations like dosa, idli and meal and wheat preparation roti are given in table 2 .

Total iron content was $7.9 \mathrm{mg}$ in rice dosa, which was highest, followed by $4.8 \mathrm{mg}$ in roti, $3.8 \mathrm{mg}$ in meal and $1.8 \mathrm{mg}$ in idli, with significant difference between preparations $(p<0.05)$ bioavailable iron was $2.037 \mathrm{mg}$ in dosa, $0.32 \mathrm{mg}$ in meal, $0.250 \mathrm{mg}$ in roti and $0.124 \mathrm{mg}$ in idli with significant difference $(p<0.05)$ between each other.

Percent available iron was least in roti at 5.2\% against meal at $8.2 \%$, idli at $6.59 \%$ and dosa at $25.6 \%$ with significant difference between each other. Hemaltha et al., 2006 reported $23.05 \%$ availability of iron from rice and black gram combination idli. Though rice based dosa had near values with $30 \%$ of available iron.

Phytic acid is found in high concentrations in cereals, reaching 3 to $6 \%$ of the weight of the grain (Febles et al., 2002). Reduction or degradation of phytic acid has been suggested for increasing the bioavailability of minerals.
Iron bioavailability is low due to high levels of dietary phytates and fibres in millets. Processing techniques such as soaking, germination, fermentation and further cooking have been found to reduce significantly the levels of phytates and tannins by exogenous and endogenous enzymes formed during processing. Heat processing as in dosa frying, roti roasting and boiling for meal preparation softens the food matrix, releases bound iron from protein and facilitates and availability.

The digestibility and hence absorption of micronutrients such as iron is improved upon heat processing, which results in softening of the food matrix, and release of protein -bound iron, thus facilitating its absorption.

The possibility of greater availability of iron increased in pearl millet idlis because of the high iron content native pearl millet and indicate that higher iron in raw grains might increase the available iron, but this trend could not be observed in other millets, compared with other all millet idlis. The little millet idli which had highest total iron next to pearl millet idli showed lowest amount of the available iron compared to all other millet idlis, probably, because this millet was dehulled and, had high protein quantity which might have interfered with iron availability resulting in reduced available iron.

The possibility iron being transferred from frying pan or tawa cannot be ruled out because the millet foods prepared by moist cooking methods showed lower total iron, lowest available iron and percent iron availability.

Fermentation of the combination of rice and blackgramdal at both the proportions examined enormously improved the bioavailability of iron. Heat treatment of the batter further increased the total iron and availability of iron in case of dosas.

Though the iron content of few millets was high in their raw form, the total iron in idlis decreased probably due to moist processing method. Compared to millet dosas idlis had lower iron content.

Bio available iron in millet dosas was least with $2.15 \mathrm{mg}$ in little millet dosa and highest in proso millet dosa with $2.239^{\mathrm{a}} \mathrm{mg}$ and $2.03 \mathrm{mg}$ from rice dosa. Significant difference was observed between any two millet dosas and between millet dosas and 
the control rice dosa $(\mathrm{p}<0.05)$. In millet idlis available iron was minimum in little millet idli with $0.02 \mathrm{mg}$ and maximum $0.57 \mathrm{mg}$ in proso millet idli and $0.125 \mathrm{mg}$ in control rice idli. In millet rotis minimum available iron of $0.085 \mathrm{mg}$ was found in little roti and maximum was found in proso millet roti with $0.105 \mathrm{mg}$ compared to control wheat roti with $0.25 \mathrm{mg}$. In millet meals available iron was minimum in little millet meal with $0.198 \mathrm{mg}$ and maximum in proso millet meal with $1.201 \mathrm{mg}$ and rice meal with $0.32 \mathrm{mg}$, percent available iron was high in proso millet meal with $27.3 \%$, little millet meal with $5.3 \%$ and rice meal with $8.2 \%$.

Compared to control rice meal, little millet meal had lower available iron. Significant difference was found in the bioavailable iron from any two millets and between millet recipes and rice recipes $(p<0.05)$. References

Anbu Malar, M., 2015.Development of Millet Mixes, Acceptability of Millet Mix Based Recipes, their Iron Bioavailability and Popularisation. Nutrition reviews. 1-17.

AOAC, 1990. Official methods of analysis for mineral analysis. Association of Official Analytical Chemists.14 ${ }^{\text {th }}$ edition. Washing DC. USA.

AOAC. 2000. Methods of Analysis, $17^{\text {th }}$ Edition. Association of Official Analytical Chemist. Washington DC, USA.

Asp, N.G., 1987. Definition and analysis of dietary fibre. Scandinavian Journal of Gastroenterology Supplement. 129: 16-20.

Febles, C. I., Arias, A., Hardisson, A., Rodrigues, A
C and Sierra, A. 2002. Phytic acid level in wheat flours. Journal of Cereal Science. 36: 19-23.

Gopalan, C., Rama Sastri, B.V and Balasubramanian, S.C. 2009. Nutritive Value of Indian Foods. Hyderabad. India, NIN, ICMR.

Hama, F., Icard,Vernie, R., Guyot, J.P., Picq, C.J., Diawana,B., Mouquect and Rivier, C. 2011.Evoluation of the micro and macro nutrient composition of pearl millet and white sorghum during in field versus laboratory decortication. Journal of Cereal Science.54: 425-433.

Hemalatha, 2006. Studies on the bioavailability of micronutrient from Indian food. Ph.D Thesis. University of Mysore, Mysore.

Mbithi-Mwikya, S., Ooghe, W., Van Camp, J., Nagundi, D., and Huyghebaert, A. 2000. Amino acid profile after sprouting, Autoclaving and lactic acid fermentation of finger millet (Elusine coracana) and kidney beans (Phaseolus vulgaris L.) Journal of Agriculture and Food Chemistry. 48 (8): 3081-3085.

Rao, B.S.N, and Prabhavathi, T. 1978. An in vitro method for predicting the bioavailability of iron from foods. American Journal of Clinical Nutrition. 31(1): 169-175.

Veena, B., Chimmad, B.V., Naik, R.K., and Shantakumar, G. 2005. Physico-chemical and nutritional studies in barnyard millet. Karnataka Journal Agricultural Science 18 (1): 101-105.

\section{How to cite this article:}

Mounika, M., K. Uma Devi and Sucharitha Devi, S. 2017. Iron Bioavailability from Little Millet and Proso Millet Based Recipes. Int.J.Curr.Microbiol.App.Sci. 6(10): 2832-2840.

doi: https://doi.org/10.20546/ijcmas.2017.610.332 